\title{
Multiscale Detection of Sulfur Cinquefoil Using Aerial Photography
}

\author{
Bridgett J. Naylor, ${ }^{1}$ Bryan A. Endress, ${ }^{2}$ and Catherine G. Parks ${ }^{3}$ \\ Authors are ${ }^{1}$ GIS Analyst, USDA Forest Service, Pacific Northwest Research Station, La Grande, OR 97850; \\ ${ }^{2}$ Research Associate, Department of Forest Science, Oregon State University, Corvallis, OR 97331; ${ }^{3}$ Research Ecologist,
} USDA Forest Service, Pacific Northwest Research Station, La Grande, OR 97850.

\begin{abstract}
We evaluated the effectiveness of natural color aerial photography as a tool to improve detection, monitoring, and mapping of sulfur cinquefoil (Potentilla recta L.) infestations. Sulfur cinquefoil is an exotic perennial plant invading interior Pacific Northwest rangelands. Because sulfur cinquefoil produces distinctive pale yellow flowers, we timed aerial photography for early July, when the plant was at peak bloom. Photography was collected at 3 spatial scales (1:3 000, 1:6 000, and 1:12 000). A grid with 250-m spacing was superimposed over photographs of the entire study area using geographic information systems. At each grid intersection point $(n=80)$, we visually analyzed the photographs within a $404.7-\mathrm{m}^{2}(0.1$ acre $)$ circular plot, recorded sulfur cinquefoil presence, and estimated sulfur cinquefoil percent cover. Sample points on the grid were then located in the field using a global positioning system. Field data collected at each point included sulfur cinquefoil presence, percent cover, and stem density; and total vegetation composition and percent cover by life form. Results indicate that the accuracy of detecting sulfur cinquefoil increased from small to large scale. At the 1:3000 scale, sulfur cinquefoil presence was correctly identified in $76.9 \%$ of the sites, whereas at the 1:6000 and 1:12 000 scales, infestations were identified in $67.9 \%$ and $59.1 \%$ of the sites, respectively. Low-density infestations ( $<1 \%$ cover) were detected at all scales. Accuracy of percent cover estimates ranged from $33.8 \%$ to $38.0 \%$ across scales. Although tree canopy hindered detection, our results indicate that aerial photography can be used to detect sulfur cinquefoil infestations in open forests and rangelands in the Intermountain West.
\end{abstract}

\section{Resumen}

Evaluamos la efectividad de la fotografía aérea de color natural como una herramienta para mejorar la detección, monitoreo y mapeo de las infestaciones del "Sulfur cinquefoil" (Potentilla recta L.) la cual es una planta perenne exótica que esta invadiendo los pastizales interiores de la región noroeste del Pacífico. Debido a que el "Sulfur cinquefoil" produce flores de color amarillo pálido que es distintivo, programamos la fotografía para inicios de Julio, cuando la planta esta el máximo de floración. La fotografía se colectó a tres escalas espaciales (1:3 000, 1:6 000, 1:12 000). Una cuadrícula con espaciamiento de 250-m entre puntos se sobrepuso en las fotografías del área total de estudio usando sistemas de información geográfica. En cada punto de intersección de la cuadrícula $(n=80)$, analizamos visualmente las fotografías dentro de una parcela circular de 0.1-acre, registrando la presencia de "Sulfur cinquefoil" y estimamos el porcentaje de cobertura de esta especie. Los puntos de la muestra en la cuadrícula fueron localizados en el campo usando un sistema de posicionamiento global. Los datos de campo colectados en cada punto incluyeron la presencia de "Sulfur cinquefoil", el porcentaje de cobertura, la densidad de tallos, la composición total de la vegetación y el porcentaje de cobertura por forma de vida. Los resultados indican que la certeza de detectar el "Sulfur cinquefoil" aumentó de la escala pequeña a la grande. En la escala de 1:3 000 la presencia de "Sulfur cinquefoil" fue identificada correctamente en el 76.9\% de los sitios, mientras que en las escalas de 1:6 000 y 1:12 000 las infestaciones fueron identificadas en $67.9 \%$ y $59.1 \%$ de los sitios, respectivamente. Las infestaciones de baja densidad $(<1 \%$ cobertura) fueron detectadas en todas las escalas. La certeza de las estimaciones del porcentaje de cobertura varió de $33.8 \%-38.0 \%$ a través de todas las escalas. Aunque la copa de los árboles interfirieron la detección, nuestros resultados indican que la fotografía aérea puede ser usada para detectar las infestaciones de "Sulfur cinquefoil" en bosques abiertos y pastizales del oeste intermontañoso.

Key Words: remote sensing, Potentilla recta, image analysis, invasive plants, noxious weeds, exotic species, Oregon

\section{INTRODUCTION}

Sulfur cinquefoil (Potentilla recta L.) was introduced to North America before 1900. In eastern North America, sulfur cinquefoil is a minor agricultural weed (Werner and Soule 1976). However, in the drier climates of interior northwestern

Research was partially funded by the Center for Invasive Plant Management. Correspondence: Catherine Parks, USDA Forest Service, Pacific Northwest Research Station, 1401 Gekeler Lane, La Grande, OR 97850. Email: cparks01@fs.fed.us

Manuscript received 27 April 2004; manuscript accepted 22 November 2004.
North America, it has broad ecological amplitude, forms dense populations, and is considered a threat to native plant communities (Rice 1991, 1993, 1999; Rice et al. 1994). Currently, the extent of sulfur cinquefoil is not well known, and improved methods are needed for detection and mapping to aid in management efforts.

The value of remote sensing for rangeland assessment is well established. However, aerial photography has been used with limited success to detect invasive plants (Driscoll and Coleman 1974; Carneggie et al. 1983; Tueller 1989; Driscoll et al. 1997; Anderson et al. 1999; Everitt et al. 2001). We evaluated the use 


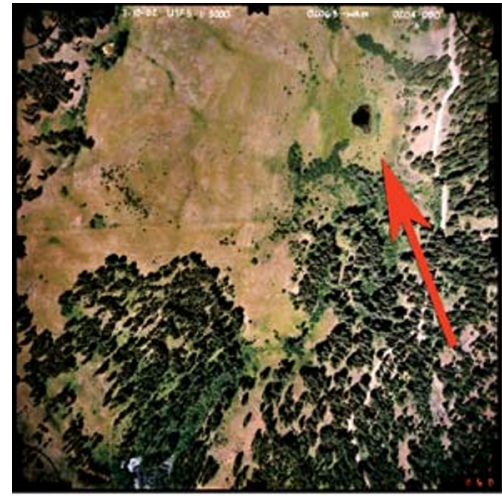

$1: 3,000$

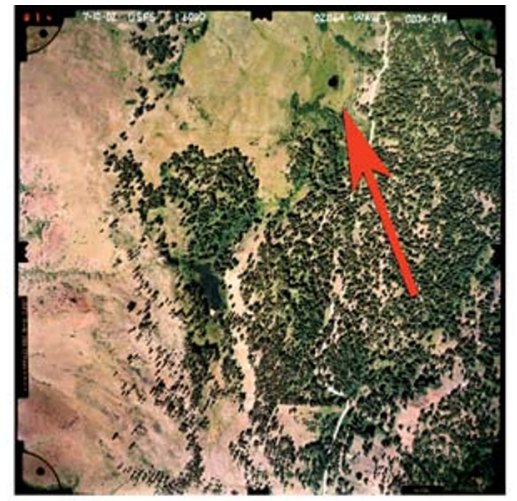

$1: 6,000$

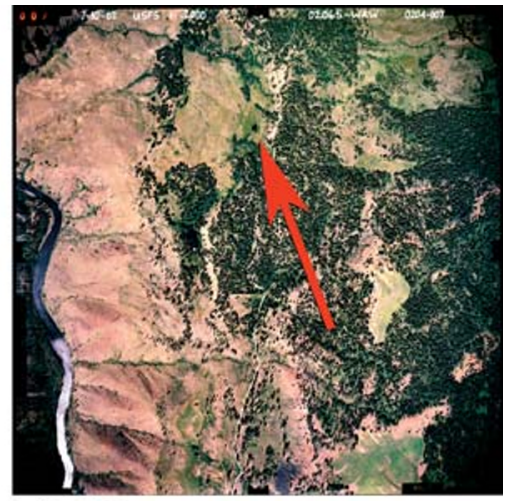

$1: 12,000$

Figure 1. Aerial photographs of a meadow infested with sulfur cinquefoil at all scales (1:3000, 1:6 000, and 1:12 000).

of natural color aerial photography at 3 spatial scales to detect sulfur cinquefoil infestations in open forest and grassland plant communities in northeastern Oregon. Our objectives were 1) to evaluate aerial photography effectiveness in detecting and estimating percent cover of sulfur cinquefoil; 2) to determine the minimum percent cover of sulfur cinquefoil detected at each flight scale; and 3) to assess this detection method as a tool for resource managers.

\section{MATERIALS AND METHODS}

\section{Aerial Photography}

Natural color photography was collected at 3 scales (1:3 000, 1:6 000, and 1:12 000) along a 6.5-km strip within the Wenaha State Wildlife Area near Troy, Oregon (Fig. 1). The study area is characterized by a matrix of abandoned agricultural fields, ponderosa pine (Pinus ponderosa P. \& C. Lawson) stands, and bunchgrass (Pseudoroegneria spicata (Pursh) A. Löve, Poa secunda J. Presl, Festuca idahoensis Elmer) plant communities. Elevation ranges from 900 to $1150 \mathrm{~m}$ within the study area. Flights were conducted during the first week in July 2002, when sulfur cinquefoil was anticipated to be at peak bloom and its distinctive pale yellow flowers contrasted best with surrounding vegetation. To validate the expected peak bloom period, we monitored sulfur cinquefoil phenology at 3 sites located within the flight line from mid June to late July. Each phenology site had 5 randomly placed, permanently marked $1-\mathrm{m}^{2}$ quadrats where we determined peak bloom by comparing relative bloom cover of sulfur cinquefoil in each quadrat during 7 weeks.

\section{Photo Interpretation}

Aerial photographs $(10 \times 10$ in) were scanned at 600 dots per inch, orthorectified, and mosaiced by using postprocessed ground control points that were collected with a real-time differential global positioning system (DGPS; ERDAS 1997, Trimble 2002). Sample locations with 250-m spacing were placed over photographs at each scale within the $6.5-\mathrm{km}$ strip. This resulted in 80 sample points for photo interpretation for the 1:12 000 and 1:6000 scales and 64 sample points for the 1:3 000 scale. Three photo interpreters recorded sulfur cinquefoil presence or absence and estimated percent cover at each sample point. They were shown photographs in advance that had verified areas of sulfur cinquefoil infestations with which to make comparisons. Each sample point was a circular area of $404.7 \mathrm{~m}^{2}$ (0.1 acre). This size was chosen because it is considered a standard minimum detection area for the 1:12 000 scale. Percent cover was grouped into 9 cover classes $(0 \%, 1 \%, 1 \%-5 \%, 5 \%-25 \%, 25 \%-50 \%, 50 \%-75 \%, 75 \%-$ $95 \%, 95 \%-99 \%, 100 \%$ ) commonly used in vegetation analysis (McCune and Grace 2002). All photo interpreters examined the photographs starting with the smallest scale $(1: 12000)$ and ending with the largest scale $(1: 3000)$ to prevent possible biased results between scales.

\section{Field Sampling}

Using real-time DGPS, we navigated to each sample point in the study area and delineated the circular plot boundary with flagging. For each plot, percent cover of sulfur cinquefoil and tree canopy cover were assigned to 1 of 9 cover classes $(0 \%$, $1 \%, 1 \%-5 \%, 5 \%-25 \%, 25 \%-50 \%, 50 \%-75 \%, 75 \%-95 \%$, $95 \%-99 \%, 100 \%)$. In addition, 12 quadrats measuring $1 \mathrm{~m}^{2}$ were systematically placed throughout each plot. Percent cover for sulfur cinquefoil and other vegetation life form categories (i.e., forbs, grasses, shrubs, and trees) was recorded and, if present, the number of sulfur cinquefoil stems was counted.

\section{Data Analysis}

Each photo interpreter's (observer's) classification accuracy was assessed at each scale (Story and Congalton 1986; Congalton 1991; Fitzgerald and Lees 1994). Data were assembled into classification error matrices by observer and scale comparing observer interpretations to field-sampled reference data at each site. Overall accuracy was calculated as a percentage of the sample sites that were correctly classified (Story and Congalton 1986; Congalton 1991). An additional 2 accuracies were calculated for each classification category: 1) producer's accuracy, which identifies the likelihood that a ground-truthed site is correctly classified; and 2) user's accuracy, which identifies the likelihood that the photo-interpreted result truly represents that category in the field (Story and Congalton 1986; Congalton 1991). Two groups of error matrices were created to analyze the photo interpreters' accuracy of estimating presence and absence of sulfur cinquefoil, and sulfur cinquefoil percent cover. Sulfur cinquefoil cover classes $>5 \%$ were merged for the analysis because of low sample sizes. 
Table 1. Number of plots sampled in each sulfur cinquefoil cover class in northeastern Oregon $(n=79)$.

\begin{tabular}{lc}
\hline Sulfur cinquefoil cover class (\%) & Number of sample sites \\
\hline 0 & 20 \\
$<1$ & 35 \\
$1-5$ & 10 \\
$5-25$ & 9 \\
$25-50$ & 4 \\
$50-75$ & 1 \\
\hline
\end{tabular}

Summary statistics were used to evaluate relationships of sulfur cinquefoil cover and tree canopy cover with correctly detecting the presence of sulfur cinquefoil (SAS 2000). All categories with tree canopy cover $>50 \%$ were combined because there were few plots.

One plot was dropped from all analyses because a DGPS malfunction resulted in a loss of sample point location data.

\section{RESULTS}

\section{Field Data}

Sulfur cinquefoil was found in $74.7 \%$ of our sampled plots (59 of 79 plots). Percent cover of sulfur cinquefoil ranged from $<1 \%$ to $50 \%-75 \%$ cover; $82.3 \%$ of the plots $(n=65)$ had $\leq 5 \%$ sulfur cinquefoil cover (Table 1). Infestations were found under tree canopy; however, areas without tree overstory had the greatest densities of sulfur cinquefoil. Of the sites without tree canopy cover, $80.8 \%(n=21)$ were infested with sulfur cinquefoil and the maximum stem density recorded was 154 stems $\mathrm{m}^{-2}\left(\right.$ mean $=29$ stems $\left.\mathrm{m}^{-2}\right)$. On sites with $>50 \%$ tree canopy cover, $50 \%(n=4)$ were infested and the maximum sulfur cinquefoil stem density was $1 \mathrm{stem} \mathrm{m}^{-2}$ (mean $=1 \mathrm{stem}$ $\mathrm{m}^{-2}$ ).

\section{Photo Interpretation}

Photo interpreters were able to detect sulfur cinquefoil at all 3 scales of photography (Table 2; Fig. 2). The mean overall accuracy for the 3 photo interpreters to correctly detect sulfur cinquefoil presence or absence was $76.9 \%$ at the $1: 3000$ scale, $67.9 \%$ at the $1: 6000$ scale, and $59.1 \%$ at the $1: 12000$ scale (Fig. 2). Mean overall accuracy increased approximately $10 \%$ for each scale, resulting in an $18 \%$ increase in our detection capability from the smallest to largest scales. In addition, the mean producer's accuracy for sites with sulfur cinquefoil present increased from $49.7 \%$ to $82.3 \%$ from the smallest to largest scales. Despite the trend in increasing accuracy with increasing scale, we were more likely to have a false-positive result at larger scales than at smaller scales (Fig. 2). For the $1: 12000$ scale, we correctly identified $86.7 \%$ of the sites that did not contain sulfur cinquefoil, whereas at the 1:6 000 and 1:3 000 scales, we correctly identified only $58.3 \%$ and $56.4 \%$ of these sites, respectively (mean producer's accuracy for sites with no sulfur cinquefoil; Table 2).

As sulfur cinquefoil cover increased, we had a greater probability of detecting its presence (Fig. 3). However, new or small infestations $(<1 \%$ cover $)$ were detected in $73.8 \%$ of the sites at the $1: 3000$ scale, $57.1 \%$ of the sites at the $1: 6000$ scale, and $41.0 \%$ of the sites at the 1:12 000 scale.
Table 2. Classification accuracies for photo interpretations of sulfur cinquefoil absence or presence at all scales, and mean classification accuracies of the 3 interpretations.

\begin{tabular}{lccc}
\hline \multicolumn{4}{c}{ Overall accuracy $(\%)$} \\
\hline Scale & $1: 3000$ & $1: 6000$ & $1: 12000$ \\
\hline Observer 1 & 69.4 & 60.8 & 62.0 \\
Observer 2 & 80.6 & 74.7 & 60.8 \\
Observer 3 & 80.6 & 68.4 & 54.4 \\
Mean & 76.9 & 67.9 & 59.1
\end{tabular}

\begin{tabular}{|c|c|c|c|c|c|c|c|}
\hline \multicolumn{4}{|c|}{ Producer's accuracy, absent (\%) } & \multicolumn{4}{|c|}{ User's accuracy, absent (\%) } \\
\hline Scale & $1: 3000$ & $1: 6000$ & $1: 12000$ & Scale & $1: 3000$ & $1: 6000$ & $1: 12000$ \\
\hline Observer 1 & 84.6 & 85.0 & 95.0 & Observer 1 & 39.3 & 37.8 & 39.6 \\
\hline Observer 2 & 38.5 & 50.0 & 75.0 & Observer 2 & 55.6 & 50.0 & 36.6 \\
\hline Observer 3 & 46.2 & 40.0 & 90.0 & Observ & 54.5 & 38.1 & 34.6 \\
\hline Mean & 56.4 & 58.3 & 86.7 & Mean & 49.8 & 42.0 & 36.9 \\
\hline
\end{tabular}

\begin{tabular}{|c|c|c|c|c|c|c|c|}
\hline \multicolumn{4}{|c|}{ Producer's accuracy, present (\%) } & \multicolumn{4}{|c|}{ User's accuracy, present (\%) } \\
\hline Scale & $1: 3000$ & $1: 6000$ & $1: 12000$ & Scale & $1: 3000$ & $1: 6000$ & $1: 1200$ \\
\hline Observer 1 & 65.3 & 52.5 & 50.8 & Observer 1 & 94.1 & 91.2 & 96.8 \\
\hline Observer 2 & 91.8 & 83.1 & 55.9 & Observer 2 & 84.9 & 83.1 & 86.8 \\
\hline Observer 3 & 89.8 & 78.0 & 42.4 & Observer 3 & 86.3 & 79.3 & 92.6 \\
\hline Mean & 82.3 & 71.2 & 49.7 & Mean & 88.4 & 84.5 & 92.1 \\
\hline
\end{tabular}

Tree canopy cover affected our ability to detect sulfur cinquefoil infestations at all scales (Fig. 4). At the 1:12 000 scale, correct detection of sulfur cinquefoil presence decreased from $61.9 \%$ with zero canopy cover to $41.7 \%$ with $>50 \%$ canopy cover. Correct detection of sulfur cinquefoil using the 1:6 000 scale decreased substantially from $87.3 \%$ with zero canopy cover to $33.3 \%$ with $>50 \%$ canopy cover. Similarly, for the $1: 3000$ scale, there was a reduction in correct detection from $84.1 \%$ with zero canopy cover to $50 \%$ with $>50 \%$ canopy cover.

The mean overall accuracy of sulfur cinquefoil cover estimates ranged from $33.8 \%$ to $38.0 \%$ among the scales

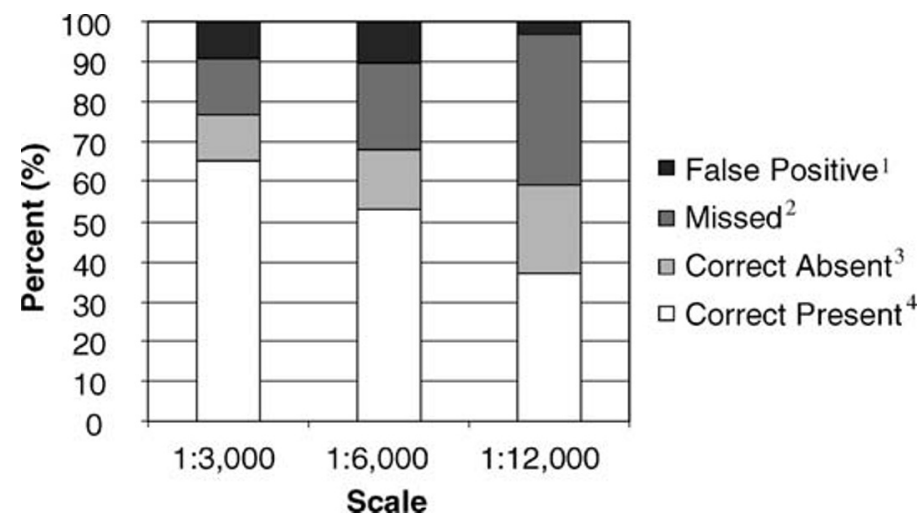

Figure 2. Mean accuracy of 3 photo interpreters in determining sulfur cinquefoil presence in aerial photographs taken at 3 scales. ${ }^{1}$ Percent of sites classified as having sulfur cinquefoil present when it was not. ${ }^{2}$ Percent of sites classified as having sulfur cinquefoil absent when it was present. ${ }^{3}$ Percent of sites correctly classified as having sulfur cinquefoil absent. ${ }^{4}$ Percent of sites correctly classified as having sulfur cinquefoil present. 


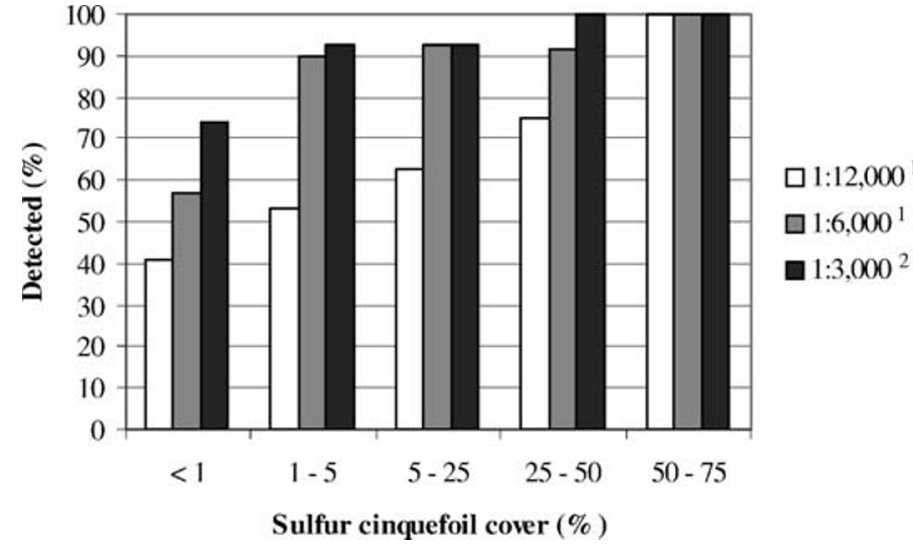

Figure 3. Correctly detected sulfur cinquefoil presence (mean values) by photo interpreters for 5 sulfur cinquefoil cover classes at 3 photography scales. ${ }^{1} n=35,10,9,4,1$ for $<1 \%, 1 \%-5 \%, 5 \%-25 \%, 25 \%-50 \%$, and $50 \%-75 \%$ cover classes, respectively. ${ }^{2} n=28,9,9,2,1$ for $<1 \%$, $1 \%-5 \%, \quad 5 \%-25 \%, \quad 25 \%-50 \%$, and $50 \%-75 \%$ cover classes, respectively.

(Table 3). As indicated by the accuracies, observers were unable to provide an accurate classification of cover, regardless of cover class.

\section{DISCUSSION}

This study addresses a critical question central to exotic plant invasion of rangelands: How can managers accurately and cost effectively inventory and monitor nonnative invasive plants across large landscapes? Owing to limited financial and personnel resources to sample, inventory, and monitor large areas, the development of methods such as remote sensing to detect invasive species is needed. Although previous studies report mixed success with using remote sensing (Carneggie et al. 1983; Johnson 1999; Lass et al. 2002; Ramsey et al. 2002), our results indicate that 1) natural color aerial photography can be used to identify sulfur cinquefoil infestations,

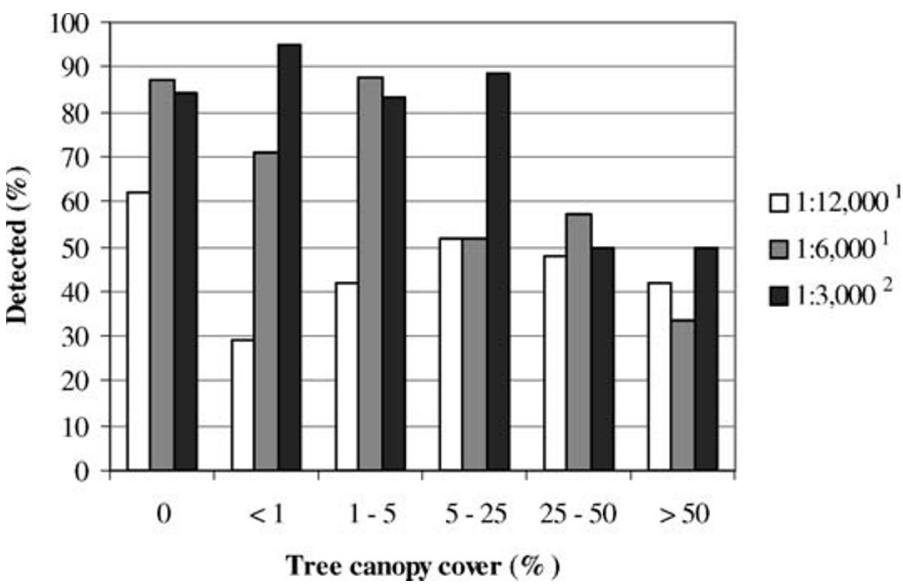

Figure 4. Correctly detected sulfur cinquefoil presence (mean values) by photo interpreters for 6 tree canopy cover classes at 3 photography scales. ${ }^{1} n=21,8,8,11,7,4$ for $0 \%,<1 \%, 1 \%-5 \%, 5 \%-25 \%, 25 \%-$ $50 \%$, and $>50 \%$ cover classes, respectively. ${ }^{2} n=21,7,6,9,4,2$ for 0 , <1\%, $1 \%-5 \%, 5 \%-25 \%, 25 \%-50 \%$, and $>50 \%$ cover classes, respectively.
Table 3. Classification accuracies for photo interpretations of percent sulfur cinquefoil cover at all scales and mean classification accuracies of the 3 interpretations.

\begin{tabular}{lccc}
\hline \multicolumn{4}{c}{ Overall accuracy $(\%)$} \\
\hline Scale & $1: 3000$ & $1: 6000$ & $1: 12000$ \\
\hline Observer 1 & 40.3 & 40.5 & 41.8 \\
Observer 2 & 33.9 & 35.4 & 39.2 \\
Observer 3 & 33.9 & 25.3 & 32.9 \\
Mean & 36.0 & 33.8 & 38.0
\end{tabular}

\begin{tabular}{|c|c|c|c|c|c|c|c|}
\hline \multicolumn{4}{|c|}{ Producer's accuracy, $0 \%(\%)$} & \multicolumn{4}{|c|}{ User's accuracy, 0\% (\%) } \\
\hline ale & $1: 3000$ & $1: 6000$ & $1: 12000$ & Scale & $1: 3000$ & $1: 6000$ & $1: 12$ \\
\hline & 84.6 & 85.0 & & & 9.3 & 7.8 & \\
\hline er 2 & 38.5 & . & 75.0 & 2 & 55.6 & 0.0 & 6 \\
\hline & 46.2 & 40.0 & & $\mathrm{Ob}$ & 54. & 38.1 & 34.6 \\
\hline an & 56.4 & 58.3 & 86.7 & Mean & 49.8 & 42.0 & 36.9 \\
\hline
\end{tabular}

\begin{tabular}{|c|c|c|c|c|c|c|c|}
\hline \multicolumn{4}{|c|}{ Producer's accuracy, $1 \%(\%)$} & \multicolumn{4}{|c|}{ User's accuracy, $1 \%(\%)$} \\
\hline Scale & $1: 3000$ & $1: 6000$ & $1: 12000$ & Scale & $1: 3000$ & $1: 6000$ & $1: 12000$ \\
\hline Observer 1 & 39.3 & 17.1 & 25.7 & Observer 1 & 50.0 & 37.5 & 69.2 \\
\hline Observer 2 & 28.6 & 22.9 & 28.6 & Observer 2 & 47.1 & 40.0 & 66.7 \\
\hline Observer 3 & 10.7 & 5.7 & 2.9 & Observer 3 & 60.0 & 22.2 & 50.0 \\
\hline Mean & 26.2 & 15.2 & 19.0 & Mean & 52.4 & 33.2 & 62.0 \\
\hline
\end{tabular}

\begin{tabular}{|c|c|c|c|c|c|c|c|}
\hline \multicolumn{4}{|c|}{ Producer's accuracy, $1 \%-5 \%(\%)$} & \multicolumn{4}{|c|}{ User's accuracy, $1 \%-5 \%(\%)$} \\
\hline Scale & $1: 3000$ & $1: 6000$ & $1: 12000$ & Scale & $1: 3000$ & $1: 6000$ & $1: 12000$ \\
\hline Observer 1 & 22.2 & 40.0 & 30.0 & Observer 1 & 18.2 & 40.0 & 23.1 \\
\hline Observer 2 & 11.1 & 30.0 & 30.0 & Observer 2 & 6.3 & 17.7 & 25.0 \\
\hline Observer 3 & 55.6 & 30.0 & 0.0 & Observer 3 & 20.8 & 14.3 & 0.0 \\
\hline Mean & 29.6 & 33.3 & 20.0 & Mean & 15.1 & 24.0 & 16.0 \\
\hline
\end{tabular}

\begin{tabular}{|c|c|c|c|c|c|c|c|}
\hline \multicolumn{4}{|c|}{ Producer's accuracy, $>5 \%(\%)$} & \multicolumn{4}{|c|}{ User's accuracy, $>5 \%(\%)$} \\
\hline Scale & $1: 3000$ & $1: 6000$ & $1: 12000$ & Scale & $1: 3000$ & $1: 6000$ & $1: 12000$ \\
\hline Observer 1 & 8.3 & 35.7 & 14.3 & Observer 1 & 100.0 & 62.5 & 40.0 \\
\hline Observer 2 & 58.3 & 50.0 & 21.4 & Observer 2 & 35.0 & 31.8 & 27.3 \\
\hline Observer 3 & 58.3 & 50.0 & 50.0 & Observer 3 & 31.8 & 25.0 & 41.2 \\
\hline Mean & 41.7 & 45.2 & 28.6 & Mean & 55.6 & 39.8 & 36.2 \\
\hline
\end{tabular}

even at low densities; 2) sulfur cinquefoil is more easily detected in large-scale photos than in small-scale photos, although sulfur cinquefoil was readily detected at all scales; 3) aerial photography is not reliable for accurately determining percent cover of infestations, but by further generalizing sulfur cinquefoil cover classes, broad estimates of percent cover may be obtained; and 4) tree canopy cover inhibits detection, and therefore aerial photography use is most effective in grassland communities or open forests.

The user's accuracy is a gauge to inform us how confident we can be in the classifications made. However, given that our main objective for this study was to assess the ability to detect sulfur cinquefoil by using aerial photography, the overall and producer's accuracies were key in our analysis of the classification accuracy assessment.

The decrease in producer's accuracy for sulfur cinquefoil absence from smallest to largest scale (i.e., more false positives) 
may be due to the changes in texture and color between photography scales. The photography detail at the 1:12 000 scale is obviously less than at the 1:6 000 and 1:3 000 scales, and may not cause the photo interpreters to falsely classify similarly colored vegetation as sulfur cinquefoil as often.

The range of accuracy among observers is relatively large compared with the range across scales. For example, the producer's accuracy for sites with sulfur cinquefoil present has a range of $26.5 \%$ for the $1: 3000$ scale, $30.6 \%$ for the $1: 6000$ scale, and $13.5 \%$ for the $1: 12000$ scale, which is considerable relative to the range of mean values across scales of $32.6 \%$ (Table 2 ). Similarly, the range among observers for the producer's accuracy for sites with sulfur cinquefoil absent is $46.1 \%$ for the $1: 3000$ scale, $45.0 \%$ for the $1: 6000$ scale, $20.0 \%$ for the 1:12 000 scale, and $30.2 \%$ across scales (Table 2). The ranges among observers for the overall accuracy and the user's accuracy are less than the producer's accuracy but so are the ranges across scales for each, suggesting the trend is consistent in all of the accuracy groups. These results indicate an opportunity to improve the detection method by decreasing interobserver variability. This may be done by using more observer training sites with known sulfur cinquefoil cover to standardize estimates.

Two additional challenges may limit the widespread use of this methodology. First, aerial photographs must be taken during peak bloom to maximize sulfur cinquefoil detection, which requires observing plant phenology during the same season of scheduled photography. Second, in some areas there may be other plant species with similarly colored flowers that could confuse interpreters. In the Pacific Northwest, buckwheat (Eriogonum spp.) and lupine (Lupinus spp.) with yellow flowers could potentially cause interpretation errors.

Our approach may be particularly valuable to land managers seeking to assess sulfur cinquefoil invasions across large or inaccessible areas. We believe it may be feasible to capitalize on existing aerial surveys and photographs to detect sulfur cinquefoil populations. For example, the US Department of Agriculture (USDA) Forest Service and the Oregon Department of Forestry conduct regular flights for resource applications, many of which occur when sulfur cinquefoil is flowering. Moreover, the USDA Forest Service regularly collects Aerial Resource Photography by using natural color aerial photography at 1:12 000 scale, which may provide a valuable data source. We suggest that land managers consider 1) the size of the area being surveyed; 2) anticipated infestation densities; 3) project scope; and 4) available funding before determining what scale of photography to use. The 1:3 000 scale is most accurate overall, but for managers primarily interested in identifying major infestations over large areas, the 1:12 000 scale may be more appropriate and still provide $>70 \%$ detection of infestations that have $>25 \%$ sulfur cinquefoil cover.

Our approach represents a relatively easy to implement and highly accurate method for detecting sulfur cinquefoil. Because nonnative invasive plants are easiest to control when populations are small, land managers reap substantial financial and workforce benefits from using cost-effective and reliable detection and monitoring methods. Based on our success in detecting sulfur cinquefoil, we plan to extend the scope of our work. Future study will determine the feasibility of delineating sulfur cinquefoil infestations in our study site and the nearby Wenaha-Tucannon Wilderness Area on the Umatilla National Forest.

\section{ACKNOWLEDGMENTS}

The authors thank R. Harris for organizing flights and conducting photography, M. Golden for help in study design and development, and L. Spiegel, T. Wurtz, R. Taylor, J. Hayes, K. Bigler Cole, and T. Max for manuscript review.

\section{LITERATURE CITED}

Anderson, G. L., C. W. Prosser, S. Hagar, and B. Foster. 1999. Change detection of leafy spurge infestations using aerial photography and geographic information systems. In: P. T. Tueller [ED.]. Proceedings of the 17th Biennial Workshop on Color Aerial Photography and Videography in Resource Assessment; 5-7 May, 1999; Bethesda, MD: American Society for Photogrammetry and Remote Sensing. p 223-230.

Carneggie, D. M., B. J. Schrumpf, and D. M. Mouat. 1983. Rangeland applications. In: R. N. Colwell [ED.]. Manual of remote sensing. Falls Church, VA: American Society of Photogrammetry. p 2325-2364.

Congalton, R. G. 1991. A review of assessing the accuracy of classifications of remotely sensed Data. Remote Sensing Environment 37:35-46.

Driscoll, R. S., and M. D. Coleman. 1974. Color for shrubs. Photogrammetric Engineering 40:451-459.

Driscoll, R. S., J. H. Everitt, R. H. HaAs, and P. T. Tueller. 1997. Ranges and range management. In: W. R. Philipson [ED.]. Manual of photographic interpretation. Bethesda, MD: American Society for Photogrammetric and Remote Sensing. p 441-474.

ERDAS. 1997. ERDAS field guide. 4th ed. Atlanta, GA: ERDAS, Inc. 656 p.

Everitt, J. H., D. E. Escobar, and M. R. Davis. 2001. Reflectance and image characteristics of selected noxious rangeland species. Journal of Range Management 54:A106-A120.

Fitzgerald, R. W., and B. G. Lees. 1994. Assessing the classification accuracy of multisource remote sensing data. Remote Sensing of Environment 47: 362-368.

JMP. 2000. Statistical Analysis System [SAS], Version 4.0.2. Cary, NC: SAS Institute. JoHnson, D. E. 1999. Surveying, mapping, and monitoring noxious weeds on rangelands. In: R. L. Sheley and J. K. Petroff [EDS.]. Biology and management of noxious rangeland weeds. Corvallis, OR: Oregon State University Press, p 19-35.

Lass, L. W., D. C. Thill, B. Shaffi, and T. S. Prather. 2002. Detecting spotted knapweed (Centaura maculosa) with hyperspectral remote sensing technology. Weed Technology 16(2):426-432.

McCune, B., and J. B. Grace. 2002. Analysis of ecological communities. Glenden Beach, OR: MjM Software Designs, 300 p.

Ramsey, E. W., G. A. Nelson, S. K. Sapkota, E. B. Seeger, and K. D. Martella. 2002. Mapping Chinese tallow with color-infrared photography. Photogrammetric Engineering and Remote Sensing 68(3):251-255.

RICE, P. M. 1991. Sulfur cinquefoil: a new threat to biological diversity. Western Wildlands. 17:234-240.

RICE P. M. 1993. Distribution and ecology of sulfur cinquefoil in Montana, Idaho and Wyoming. Final report. Helena, MT: Montana Dept. of Agriculture. $11 \mathrm{pp}$.

Rice, P. M. 1999. Sulfur cinquefoil. In: R. L. Sheley and J. K. Petroff [eds.]. Biology and management of noxious rangeland weeds. Corvallis: Oregon State University Press. p 382-388.

Rice, P. M., C. A. Lacey, J. R. Lacey, and R. Johnson. 1994. Sulfur cinquefoil biology, ecology and management in pasture and rangeland. Extension Bulletin 109. Bozeman, MT: Montana State University. 9 p.

Story, M., and R. G. Congalton. 1986. Accuracy assessment: a user's perspective. Photogrammetric Engineering and Remote Sensing 52(3):397-399.

Trimble Navigation LImIted. 2002. GPS Pathfinder office: Getting started guide. Version 2.90. Sunnyvale, CA: Trimble Navigation Limited Mapping and GIS Division.

Tueller, P. T. 1989. Remote sensing technology for rangeland management applications. Journal of Range Management 42:442-453.

Werner, P. A., And J. D. Soule 1976. The biology of Canadian weeds. 18. Potentilla recta L., P. norvegica L. and P. argenta L. Canadian Journal of Plant Science 56:591-603. 